\title{
PENGARUH INSENTIF DAN DISIPLIN KERJA TERHADAP KINERJA KARYAWAN PADA PT. BANK PERKREDITAN RAKYAT (BPR) PIJER PODI KEKELENGEN KANTOR CABANG MEDAN
}

\author{
Suriani \\ Alumni Jurusan Manajemen Fakultas Ekonomi Universitas Negeri Medan \\ Aprinawati \\ Dosen Jurusan Manajemen Fakultas Ekonomi Universitas Negeri Medan
}

\begin{abstract}
Abstrak
This study aims to determine the effect of Incentives and Discipline on Employee Performance at PT. Bank Perkreditan Rakyat (BPR) Pijer Podi Kekelenegen Kantor Cabang Medan. The research was conducted on PT. Bank Perkreditan Rakyat (BPR) Pijer Podi Kekelenegen Kantor Cabang Medan with a population of as many as 40 people with using total sampling. Data collection techniques used were through questionnaires (questionnaire) that is by distributing questionnaires to a sample (respondents) and collect them again. The data analysis technique used is the Multiple Linear Regression. Before the data were regressed in the first test of association between the independent variable data to test for normality, multicollinearity, and heterocedasticity. To determine the contribution of factor incentives and discipline to employee performance used formula coefficient of determination $\left(R^{2}\right)$. The result showed obtained that by the regression equation $Y=6,505+0,532 X_{1}+0,247 X_{2}+e$. And showed that simultaneous incentives and discipline on employee performance at PT. Bank Perkreditan Rakyat (BPR) Pijer Podi Kekelenegen Kantor Cabang Medan, where the value of $F$ count $=15,215>F$ table $=3,24$ with level of significant $(\alpha) 0,000<0,05$. Coefficient of determination (adjusted $R$ square) of 0,451 means that the influence of incentives and discipline on employee performance at PT. Bank Perkreditan Rakyat (BPR) Pijer Podi Kekelenegen Kantor Cabang Medan 45,1\% and the remining 54,9\% is influenced by other variables outside of research. Conclusions from the research that there is a positive and significant effect of incentives and discipline on employee performance at PT. Bank Perkreditan Rakyat (BPR) Pijer Podi Kekelenegen Kantor Cabang Medan.
\end{abstract}

Keywords: Incentives, Discipline, Employee Performance

\section{PENDAHULUAN}

Pengelolaan SDM yang baik merupakan kunci sukses tercapainya tujuan instansi. Untuk menilai kualitas dari SDM yang ada dapat diukur dari kinerja karyawan. Hasil kerja karyawan merupakan hasil kerja secara kualitas dan kuantitas yang dicapai seorang karyawan dalam melaksanakan tugas sesuai dengan tanggung jawab yang diberikan. Di dalam suatu instansi seringkali menghasilkan kualitas kerja yang berbeda-beda setiap individu pegawai.

Kinerja adalah hasil kerja yang dapat dicapai oleh seseorang atau sekelompok orang dalam suatu organisasi, sesuai dengan wewenang dan tanggung jawab masing-masing dalam rangka upaya mencapai tujuan organisasi yang bersangkutan secara legal, tidak melanggar hukum dan sesuai dengan moral maupun etika. 
Dalam suatu instansi seringkali hanya menuntut kinerja yang tinggi pada para karyawan, tanpa melihat faktorfaktor yang mempengaruhi. Padahal faktor mendasar dalam menunjang kinerja seperti insentif dan disiplin kerja harus diperhatikan juga demi meningkatnya kinerja karyawan.

Pemberian insentif sangat penting bagi karyawan karena setiap anggota dari suatu organisasi mempunyai kepentingan dan tujuan tersendiri ketika ia bergabung pada organisasi tersebut. Bagi sebagian karyawan, harapan untuk mendapatkan uang adalah satusatunya alasan untuk bekerja, namun yang lain berpendapat bahwa uang hanyalah salah satu dari banyak kebutuhan yang terpenuhi melalui kerja.

Salah satu cara efektif yang dapat meningkatkan kinerja karyawan adalah dengan penerapan sistem insentif. Pemberian insentif ini dapat memberikan suatu dorongan bagi karyawan untuk bekerja lebih baik lagi dan membuatnya lebih loyal terhadap perusahaan dibandingkan yang tidak bekerja. Untuk menjamin tercapainya keselarasan tujuan, pimpinan organisasi bisa memberikan perhatian dengan memberikan insentif, karena insentif merupakan bagian dari hubungan timbal balik antara organisasi dengan sumber daya manusia.

Insentif penting juga bagi perusahaan karena mencerminkan upaya suatu perusahaan untuk mempertahankan sumber daya manusianya. Pemberian kompensasi baik berupa pengupahan dan balas jasa jika tidak dilaksanakan secara tepat maka perusahaan akan kehilangan para karyawannya. Oleh karena itu insentif merupakan hal yang penting untuk dapat mendorong semangat karyawan sehingga menghasilkan kinerja yang baik.

Selain dari pemberian insentif, disiplin kerja juga perlu di perhatikan oleh pihak perusahaan. Disiplin kerja adalah suatu keadaan tertib dimana seseorang atau sekelompok orang yang tergabung dalam organisasi tersebut berkehendak mematuhi dan menjalankan peraturan- peraturan perusahaan baik yang tertulis maupun tidak tertulis dengan dilandasi kesadaran dan keinsyafan akan tercapainya suatu kondisi antara keinginan dan kenyataan dan diharapkan agar para karyawan memiliki sikap disiplin yang tinggi dalam bekerja sehingga menghasilkan kinerja yang baik.

PT.Bank Perkreditan Rakyat Pijer Podi Kekelengen (PT.BPR PPK) Kantor Cabang Medan, Jl.Karet Raya no. 19-20, Kel. Pokok Mangga, Kec. Medan Tuntungan, Kota Medan dengan jumlah karyawan 40 orang merupakan lembaga keuangan bank yang menerima simpanan hanya dalam bentuk deposito berjangka, tabungan, dan/atau bentuk lainnya yang dipersamakan dan mengkreditkan/ menyalurkan dana sebagai usaha BPR.

Sejak dulu salah satu upaya yang dilakukan perusahaan ini untuk mendorong karyawan agar berkinerja yang baik, yaitu dengan cara memberikan insentif yang dilakukan pada setiap bulan terhadap karyawan yang dianggap memiliki kinerja yang baik. Pada perusahaan ini karyawan sangat ditargetkan khususnya dalam mencari nasabah supaya tujuan perusahaan dapat tercapai sesuai visi dan misi. Akan tetapi belakangan 
upaya tersebut terdapat fenomena masalah dalam penerapannya.

Melalui wawancara yang penulis lakukan dengan beberapa karyawan, karyawan mengeluhkan bahwa mereka sudah bekerja untuk memenuhi target sebaik dan semaksimal mungkin tetapi perusahaan terkadang tidak memberikan mereka insentif sesuai dengan kinerja yang mereka hasilkan. Sehingga hal ini membuat karyawan merasa kurang puas dan memiliki kinerja yang menurun. Hal ini menunjukkan bahwa perusahaan belakangan ini kurang memperhatikan dalam hal pemberian insentif terhadap karyawan yang sudah bekerja dengan baik pada perusahaan tersebut.

Selain itu, fenomena lain pada saat penulis melakukan pengamatan masih banyak terlihat meja yang kosong pada saat jam kerja. Sementara masih ada beberapa nasabah yang mengantri untuk melakukan transaksi. Dengan terjadinya fenomena-fenomena diatas dapat menyebabkan kinerja karyawan menurun. Karena imbalan yang mereka terima kurang sesuai dengan yang mereka harapkan. Selain itu dari segi disiplin diatas masih termasuk dalam kategori belum maksimal sehingga dapat kemungkinan menyebabkan kinerja karyawan juga menurun.

\section{METODE PENELITIAN \\ Lokasi Penelitian}

Penelitian ini dilakukan pada PT. Bank Perkreditan Rakyat Pijer Podi Kekelengen Kantor Cabang Medan yang berlokasi di Jl. Karet Raya no. 19-20, Kel. Pokok Mangga, Kec. Medan Tuntungan Kota Medan.

\section{Populasi dan Sampel}

Populasi dan sampel dalam penelitian ini adalah seluruh karyawan pada PT. Bank Perkreditan Rakyat Pijer Podi Kekelengen Kantor Cabang Medan yang berjumlah 40 orang, yaitu terdiri dari 29 perempuan dan 11 laki- laki.

Teknik Analisis

Untuk mengetahui pengaruh insentif $\left(\mathrm{X}_{1}\right)$ dan disiplin kerja $\left(\mathrm{X}_{2}\right)$ terhadap kinerja karyawan (Y) pada PT. Bank Perkreditan Rakyat Pijer Podi Kekelengen Kantor Cabang Medan maka peneliti menggunakan teknik analisis regresi berganda (Riduwan, 2007:142) dengan rumus:

Dimana :

$$
\mathbf{Y}=\mathbf{a}+\mathbf{b}_{1} \mathbf{X}_{1}+\mathbf{b}_{2} \mathbf{X}_{2}+\mathbf{e}
$$

$$
\begin{array}{ll}
\mathrm{Y} & =\text { Kinerja karyawan } \\
\mathrm{a} & =\text { Konstanta } \\
\mathrm{b}_{1}, \mathrm{~b}_{2} & =\text { Koefisien regresi } \\
\mathrm{X}_{1} & =\text { Insentif } \\
\mathrm{X}_{2} & =\text { Disiplin kerja } \\
\mathrm{e} & =\text { Standar error }
\end{array}
$$

\section{Pengujian Hipotesis}

Uji $F$ dilakukan untuk membuktikan hipotesis awal tentang pengaruh insentif $\left(\mathrm{X}_{1}\right)$ dan disiplin kerja $\left(\mathrm{X}_{2}\right)$ secara bersama-sama sebagai variabel bebas terhadap kinerja karyawan (Y) sebagai variabel terikat dengan rumus sebagai berikut (Sugiyono, 2006:190):

Dimana :

$$
\mathrm{Fh}=\frac{R^{2} / K}{\left(1-R^{2}\right) \rho(n-k-1)}
$$

$\mathrm{R}=$ Koefisien korelasi berganda

$\mathrm{K}=$ Jumlah Variabel Independen

$\mathrm{n}=$ Jumlah sampel

Kriterian pengujian hipotesis untuk uji $\mathrm{F}$ adalah :

1) $\mathrm{H}_{0}: \beta_{1}=0$, artinya secara bersama-sama tidak ada pengaruh antara insentif $\left(\mathrm{X}_{1}\right)$ dan disiplin 
kerja $\left(\mathrm{X}_{1}\right)$ terhadap kinerja karyawan $(\mathrm{Y})$.

2) $\mathrm{H}_{\mathrm{a}}: \beta_{1} \neq \beta_{2} \neq 0$, artinya secara bersama-sama ada pengaruh antara insentif $\left(\mathrm{X}_{1}\right)$ dan disiplin kerja $\left(\mathrm{X}_{1}\right)$ terhadap kinerja karyawan $(\mathrm{Y})$.

Sedangkan secara uji parsial atau koefisien regresi dimaksud untuk memastikan apabila variabel bebas yang terdapat dalam penelitian tersebut secara individu berpengaruh secara signifikan terhadap nilai variabel terikat. Caranya dengan melakukan pengujian koefisien regresi setiap variabel bebas dengan menggunakan uji t.

Adapun rumus yang digunakan untuk menguji masingmasing hipotesis adalah dengan uji t parsial (Riduwan,2007:125), yaitu:

$$
t_{\text {hitung }}=\frac{\sqrt[6]{m-2}}{\sqrt{n-r^{2}}}
$$

Penentuan kriteria pengambilan keputusan:

Ho diterima jika $\mathrm{t}$ hitung $<\mathrm{t}$ tabel pada $\alpha=5 \%$

Ha diterima jika $\mathrm{t}$ hitung $>\mathrm{t}$ tabel pada $\alpha=5 \%$

\section{Koefisien Determinan (R2)}

Uji ini digunakan untuk melihat kontribusi variabel bebas, yaitu Insentif $\left(\mathrm{X}_{1}\right)$ dan Disiplin Kerja $\left(\mathrm{X}_{2}\right)$ terhadap kinerja karyawan. Untuk mengukur uji koefisien determinan dapat digunakan rumus sebagai berikut:

$$
R^{2}=\frac{b\left(n \Sigma X_{1,2}\right)(\Sigma Y)}{n\left(\Sigma Y^{2}\right)-(\Sigma Y)^{2}}
$$

Pengujian - pengujian di atas dilakukan dengan bantuan program pengolahan data Statistic Packages for Social Science (SPSS) versi 17,0 for windows.

\section{HASIL PENELITIAN DAN PEMBAHASAN \\ Hasil Penelitian \\ Analisis Regresi Linier Berganda}

Untuk menguji hipotesis yang menyatakan terdapat pengaruh Insentif $\left(\mathrm{X}_{1}\right)$, Disiplin Kerja $\left(\mathrm{X}_{2}\right)$ terhadap kinerja karyawan (Y) digunakan analisis regresi linier berganda:

$$
\mathbf{Y}=\mathbf{a}+\mathbf{b}_{1} \mathbf{X}_{1}+\mathbf{b}_{2} \mathbf{X}_{2}+\mathbf{e}
$$

Berdasarkan hasil perhitungan diperoleh hasil persamaan regresi

\begin{tabular}{|c|c|c|c|c|c|}
\hline \multirow[b]{2}{*}{ Model } & \multicolumn{2}{|c|}{$\begin{array}{l}\text { Unstandardized } \\
\text { Coefficients }\end{array}$} & \multirow{2}{*}{$\begin{array}{c}\begin{array}{c}\text { Standardized } \\
\text { Coefficients }\end{array} \\
\text { Beta }\end{array}$} & \multirow[b]{2}{*}{$\mathrm{t}$} & \multirow[b]{2}{*}{ Sig. } \\
\hline & B & $\begin{array}{l}\text { Std. } \\
\text { Error }\end{array}$ & & & \\
\hline $1 \mid \begin{array}{l}\text { (Const } \\
\text { ant) }\end{array}$ & 6.505 & 3.845 & & 1.692 & .099 \\
\hline$X_{1}$ & .532 & .124 & .530 & 4.287 & .000 \\
\hline$X_{2}$ & .247 & .092 & .333 & 2.693 & .011 \\
\hline
\end{tabular}
ganda adalah sebagai berikut:

Tabel 1. Koefisien Regresi

Berdasarkan tabel di atas maka dapat dilihat nilai konstanta (nilai a) sebesar 6,505 dan untuk Insentif (nilai b) sebesar 0,532 serta untuk Disiplin Kerja (nilai $b_{2}$ ) sebesar 0,247 . Sehingga dapat diperoleh persamaan regresinya. Persamaan regresi tersebut adalah:

$$
Y=6,505+0,532 X_{1}+0,247 X_{2}+e
$$

Yang berarti:

- Konstanta sebesar 6,505 dapat diartikan bahwa jika tidak ada variabel insentif dan variabel disiplin kerja maka nilai kinerja karyawan adalah sebesar 6,505.

- Koefisien regresi variabel $X_{1}$ sebesar 0,532 menyatakan bahwa kenaikan satu satuan insentif akan meningkatkan kinerja karyawan sebesar 0,532.

- Koefisien regresi $X_{2}$ sebesar 0,247 menyatakan bahwa kenaikan satu satuan disiplin kerja akan 
meningkatkan kinerja karyawan sebesar 0,247.

\section{Uji Hipotesis}

\section{Uji Simultan (Uji F)}

Berdasarkan hasil pengujian statistic (Uji ANOVA/Uji F) dapat dilihat pada tabel hasil berikut:

Tabel 2. Hasil Uji Perhitungan

Uji F

ANOVA $^{\mathrm{D}}$

\begin{tabular}{|c|c|c|c|c|c|c|}
\hline \multicolumn{2}{|c|}{ Model } & \multirow{2}{*}{$\begin{array}{c}\begin{array}{c}\text { Sum of } \\
\text { Squares }\end{array} \\
132.126\end{array}$} & \multirow{2}{*}{$\frac{\mathrm{Df}}{2}$} & \multirow{2}{*}{\begin{tabular}{c|}
$\begin{array}{c}\text { Mean } \\
\text { Square }\end{array}$ \\
66.063
\end{tabular}} & \multirow{2}{*}{\begin{tabular}{|r|}
$F$ \\
15.21 \\
5
\end{tabular}} & \multirow{2}{*}{$\frac{\text { Sig. }}{.000}$} \\
\hline 1 & $\begin{array}{l}\text { Regres } \\
\text { sion }\end{array}$ & & & & & \\
\hline & $\begin{array}{l}\text { Residu } \\
\text { al } \\
\end{array}$ & 160.649 & 37 & 4.342 & & \\
\hline & Total & 292.775 & 39 & & & \\
\hline
\end{tabular}

a. Predictors: (Constant), $\mathrm{X}_{2}, \mathrm{X}_{1}$

b. Dependent Variabel: $Y$

Pengujian hipotesis dilakukan dengaa cara membandingkan besarnya angka $F$ pada hasil pengujian dengan Ftabel, dengan kriteria sebagai berikut:

Jika $\mathrm{F}_{\text {hitung }}>\mathrm{F}_{\text {tabel}}$, maka Ho ditolak dan Ha diterima

Jika $\mathrm{F}_{\text {hitung }}<\mathrm{F}_{\text {tabel }}$, maka Ho diterima dan Ha ditolak

Berdasarkan tabel 2 angka $\mathrm{F}$ yang diperoleh dari hasil perhitungan adalah sebesar 15,215. Sedangkan angka $\mathrm{F}_{\text {tabel }}$ dihitung dengan ketentuan yaitu taraf sinifikansi $95 \%$ dan alpha $5 \%$, serta derajat kebebasan (dk) dengan ketentuan $\mathrm{n}-2=40-2=38$ dengan nilai $\mathrm{df}=2$. Dengan ketentuan tersebut diperoleh angka $\mathrm{F}$ tabel sebesar 3,24.

Dengan diperolehnya nilai $\mathrm{F}_{\text {hitung }}=15,215$ dan $\mathrm{F}_{\text {tabel }}=3,24$, maka $\mathrm{F}_{\text {hitung }}>\mathrm{F}_{\text {tabel }}$ yang berarti bahwa Ho ditolak dan $\mathrm{Ha}$ diterima, sehingga dapat disimpulkan bahwa secara simultan terdapat pengaruh antara insentif $\left(\mathrm{X}_{1}\right)$ dan disiplin $\operatorname{kerja}\left(\mathrm{X}_{2}\right)$ terhadap kinerja karyawan (Y).

\section{Uji Parsial (Uji t)}

Uji $t$ dilakukan untuk mengetahui besarnya pengaruh secara parsial tentang variabel insentif $\left(\mathrm{X}_{1}\right)$ dan disiplin kerja $\left(\mathrm{X}_{2}\right)$ apakah memiliki pengaruh terhadap kinerja karyawan (Y).

Tabel 3. Hasil Uji t

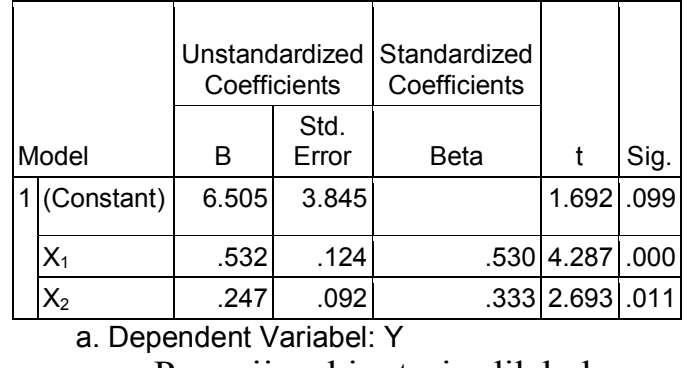

Pengujian hipotesis dilakukan denga cara membandingkan besarnya angka $t$ pada hasil pengujian dengan $t$ tabel, dengan criteria sebagai berikut: Jika $t_{\text {hitung }}>t_{\text {tabel }}$, maka Ho ditolak dan Ha diterima

Jika $\mathrm{t}_{\text {hitung }}<\mathrm{t}_{\text {tabel}}$, maka Ho diterima dan Ha ditolak

Berdasarkan tabel 3. angka $t$ yang diperoleh dari variabel insentif $\left(\mathrm{X}_{1}\right)$ hasil perhitungannya adalah sebesar 4,287. Dengan nilai signifikansi sebesar .000 dan variabel disiplin kerja $\left(\mathrm{X}_{2}\right)$ hasil perhitungannya adalah sebesar 2,693 dengan nilai signifikansi sebesar .011. Sedangkan angka $t_{\text {tabel }}$ dihitung dengan ketentuan yaitu taraf signifikansi $95 \%$ dan alpha 5\% serta derajat kebebasan (dk) dengan ketentuan $n-2=40-2=38$. Dengan ketentuan tersebut diperoleh angka $t_{\text {tabel }}$ sebesar 1,686.

Dengan diperolehnya nilai $t_{\text {hitung }}=4,287$ dan $t_{\text {tabel }}=1,686$ maka $t_{\text {hitung }}>t_{\text {tabel }}$ yang berarti bahwa Ho ditolak dan Ha diterima, sehingga dapat disimpulkan bahwa secara parsial terdapat pengaruh yang positif 
dan signifikan pada insentif $\left(\mathrm{X}_{1}\right)$ terhadap kinerja karyawan (Y).

Kemudian dengan diperolehnya nilai $t_{\text {hitung }}=2,693$ dan $\mathrm{t}_{\text {tabel }}=1,686$ maka $\mathrm{t}_{\text {hitung }}>\mathrm{t}_{\text {tabel }}$ yang berarti Ho ditolak dan Ha diterima, sehingga dapat disimpulkan bahwa secara parsial terdapat pengaruh yang positif dan signifikan pada disiplin kerja $\left(\mathrm{X}_{2}\right)$ terhadap kinerja karyawan (Y).

\section{Uji Koefisien Determinasi $\left(\mathbf{R}^{\mathbf{2}}\right)$}

Untuk mengetahui seberapa besar persentase pengaruh antara variabel bebas terhadap variabel terikat atau untuk melihat seberapa besar variabel bebas dapat menjelaskan pengaruhnya terhadap variabel terikat. Maka dilakukan pengujian koefisien determinasi $\left(\mathrm{R}^{2}\right)$ sehingga diperoleh hasil seperti tabel dibawah ini:

Tabel 5. Hasil Uji $\mathbf{R}^{2}$

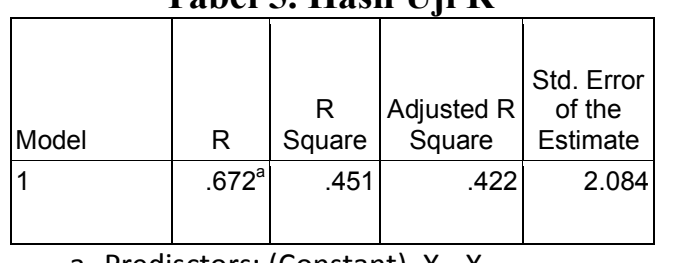

a. Predisctors: (Constant), $\mathrm{X}_{2}, \mathrm{X}_{1}$

b. Dependent Variabel: $Y$

Berdasarkan tabel di atas diperoleh nilai dari koefisien determinasi R Square sebesar 0,451. Nilai R Square menunjukkan bahwa variabel bebas mampu menjelaskan pengaruhnya terhadap variabel terikat sebesar $45,1 \%$ atau sebesar $45,1 \%$ variabel insentif dan disiplin kerja mampu menjelaskan pengaruhnya terhadap variabel kinerja karyawan. Sisanya sebesar 54,9\% dipengaruhi oleh variabel lain yang tidak dibahas dalam penelitian ini.

\section{Pembahasan Hasil Penelitian}

Dalam penelitian diperoleh data dengan cara studi pustaka, observasi, wawancara dan penyebaran kuesioner kepada karyawan PT. BPR Pijer Podi Kekelengen Kantor Cabang Medan lalu mengumpulkannya kembali. Penelitian ini dilakukan untuk mengetahui pengaruh insentif dan disiplin kerja terhadap kinerja karyawan pada PT. Bank Perkreditan Rakyat (BPR) Pijer Podi Kekelengen Kantor Cabang Medan dengan melakukan pengujian analisis data dengan menggunakan program SPSS versi 17 for windows.

Berdasarkan hasil penelitian yang dilakukan pada 40 orang resonden terbukti bahwa insentif dan disiplin kerja bersama-sama berpengaruh yang positif dan signifikan terhadap kinerja karyawan pada PT. BPR Pijer Podi Kekelengen Kantor Cabang Medan . Hal ini di dukung oleh koefisien regresi insentif sebesar 0,532 serta uji signifikansi parsial (uji t) yang menghasilkan nilai $\mathrm{t}$ hitung sebesar 4,287 dengan signifikan $0,000<0,05$. Dalam hal ini insentif berpengaruh positif dan signifikan terhadap kinerja karyawan. Artinya jika insentif yang diberikan sesuai dengan pengorbanan yang diberikan terhadap perusahaan maka kinerja akan semakin baik.

Analisis data variabel disiplin kerja dalam penelitian ini memberikan hasil yang positif dan signifikan terhadap kinerja karyawan. Yang berarti apabila disiplin kerja semakin tinggi maka akan semakin berpengaruh terhadap kinerja karyawan. Hal ini di dukung oleh koefisien disiplin kerja sebesar 0,247 serta uji signifikansi parsial (uji t) yang menghasilkan nilai $t$ hitung 
sebesar 2,693 dengan signifikan 0,011 $<0,05$.

Berdasarkan hasil penelitian terbukti bahwa insentif dan disiplin kerja mempunyai pengaruh yang positif dan signifikan terhadap kinerja karyawan dengaan koefisien 67,2 dan $\mathrm{R}$ square sebesar $45,1 \%$ dan sisanya sebesar $54,9 \%$ dijelaskan oleh faktor lain diluar variabel dalam penelitian ini. Selain itu tanda positif pada angka adjust $\mathrm{R}$ square yaitu 0,422 menunjukkan adanya arah yang sama dari ketiga variabel tersebut, artinya semakin tinggi tingkat variabel insentif dan disiplin kerja yang terjadi maka kinerja karyawan pada PT. BPR Pijer Podi Kekelengen akan semakin meningkat.

Secara simultan insentif dan disiplin kerja berpengaruh positif dan signifikan terhadap kinerja karyawan dengan uji $\mathrm{F}_{\text {hitung }}>\mathrm{F}_{\text {tabel }}$ yaitu 15,215 $>3,24$. Hasil tersebut membuktikan bahwa insentif dan disiplin kerja secara simultan berpengaruh terhadap kinerja karyawan pada PT. BPR Pijer Podi Kekelengen Kantor Cabang Medan.

Hasil perhitungan regresi linier berganda yaitu $\mathrm{Y}=6,505+$ $0,532 \mathrm{X}_{1}+0,247 \mathrm{X}_{2}+\mathrm{e}$, dapat memberikan kesimpulan bahwa nilai konstanta pada variabel terikat akan bernilai 6,505 pada saat tidak ada variabel bebasnya. Kemudian, koefisien regresi variabel bebas pertama $\left(\mathrm{X}_{1}\right)$ menyatakan bahwa setiap kenaikan satu satuannya akan meningkatkan variabel terikat sebesar 0,532 . Selanjutnya, koefisien regresi variabel bebas kedua $\left(\mathrm{X}_{2}\right)$ menyatakan bahwa setiap kenaikan satu satuannya akan meningkatkan variabel terikat sebesar 0,247.

\section{PENUTUP}

Berdasarkan hasil penelitian dan pembahasan hasil penelitiam yang telah dikemukakan dan hipotesis sebelumnya, maka beberapa kesimpulan penting yang dapat diambil dalam penelitian ini, antara lain: Variabel Insentif memiliki pengaruh yang positif dan signifikan terhadap kinerja karyawan pada PT. BPR Pijer Podi Kekelengen Kantor Cabang Medan. Hal ini dapat dilihat dari hasil uji parsial (uji t) bahwa $\mathrm{t}_{\text {hitung }}=4,287>\mathrm{t}_{\text {tabe }} \mathrm{l}=1,686$. Begitu juga dengan variabel Disiplin Kerja memiliki pengaruh yang positif dan signifikan terhadap kinerja karyawan pada PT. BPR Pijer Podi Kekelengen Kantor Cabang Medan. Hal ini dapat dilihat dari hasil uji parsial (uji t) bahwa $t_{\text {hitung }}=2,693>t_{\text {tabe }} \mathrm{l}=1,686$. Secara simultan variabel Insentif dan Disiplin Kerja memiliki pengaruh yang positif dan signifikan terhadap kinerja karyawan pada PT. BPR Pijer Podi Kekelengen Kantor Cabang Medan. Dapat dilihat dari hasil uji simultan (uji F) yaitu $F_{\text {hitung }}=15,215$ $>\mathrm{F}_{\text {tabel }}=3,24$. Insentif dan Disiplin Kerja memiliki pengaruh sebesar $45,1 \%$ terhadap kinerja karyawan pada PT. BPR Pijer Podi Kekelengen Kantor Cabang Medan.

\section{DAFTAR PUSTAKA}

A.Anwar Prabu Mangkunegara. 2006. Manajemen Sumber Daya Manusia, Remaja Rosdakarya, Bandung

Fauziah, Hujaimatul. 2012. Pengaruh Insentif dan Motivasi Kerja terhadap Kinerja Pegawai pada Kantor Dinas Bina Marga Balai Besar Pelaksanaan Jalan Nasional III SATKER Wilayah I Bandar 
Lampung. Juranal Vol. 2 no 1. Fakultas Ekonomi Universitas Sang Bumi Ruwai Jurai. Tanggal Akses 18 Desember 2014

Gorda, IGN, 2004, Manajemen Sumber Daya Manusia, Penerbit STIE Satya Dharma Singaraja

Hasibuan, Malayu SP. 2005. Manajemen Sumber Daya Manusia. Jakarta: Bumi Aksara.

Hidayat, Zainul MM. 2012. Pengaruh Lingkungan Kerja dan Disiplin Kerja Serta Motivasi Kerja terhadap Kinerja Karyawan Perusahaan Daerah Air Minum (PDAM) Kabupaten Lumajang. Jurnal Vol. 2 no 1. STIE Widya Gama Lumajang. Tanggal Akses 18 Desember 2014

Kuncoro, Mudrajad. 2009. Metode Riset Untuk Bisnis dan Ekonomi. Jakarta: Erlangga

Malthis, Robert L dan John H. Jackson. 2002. Manajemen Sumber Daya Manusia Edisi 1 Buku II. Jakarta: PT Salemba Empat

Prawatya, Dipta Adi DKK. 2012. Pengaruh Disiplin Kerja dan Budaya Organisasi terhadap Kinerja Karyawan Pabrik Minyak Kayu Putih (PMKP) di Krai Purwodadi. Jurnal VOL. 1 no 1 . Jurusan Manajmen Fakultas Ekonomi dan Bisnis Universitas Diponegoro. Tanggal Akses 18 Desember 2014

Radeswandri, DKK. 2013. Pengaruh Budaya Organisasi dan
Disiplin Kerja terhadap Kinerja Pegawai pad Badan Ketahanan Pangan Provinsi Riau.Jurnal Vol. 21 no 2. UPBJJ Universitas Terbuka Pekanbaru. Tanggal Akses 18 Desaember 2014

Riduwan. 2005. Rumus dan Data dalam Analisis Statistika. Bandung: Alfabeta

Rivai,Vethzal. 2005. Manajemen Sumber Daya Manusia untuk Perusahaan, dari Teori ke Praktik. Jakarta: PT. Raja Grafindo Persada

Robbins, Stephen P. 2006. Perilaku Organisasi. Jakarta: PT Indeks Kelompok Gramedia

Siagian, Sondang P. 2007. Manajemen Sumber Daya Manusia. Cetakan KeEmpat Belas. Jakarta: Bumi Aksara

Simamora, Hendry. 2004. Manajemen Sumber Daya Manusia. Yogyakarta: STIE YKPN

Soejiono, Imam. 2005. Teknik Memimpin Pegawai dan Pekerja. Jakarta: Jayasakti

Sugiyono. 2006. Memahami Penelitian Kualitatif. Bandung: ALFABET .2008.

Memahami Penelitian Kualitatif. Bandung: ALFABET

Syamsuddinor. 2014. Pengaruh Pemberian Insentif dan Disiplin Kerja terhadap Kinerja Karyawan pada PT.Ben Line Agencies (BLAA) Banjarmasin. Jurnal Vol. 6 No 1. Sekolah Tinggi Ilmu Manajemen Indonesia Banjarmasin. Tanggal Akses 18 Desember 2014 